\title{
Spectrophotometric Determination of Yttrium with Pyrocatechol Violet Reagent - Application to Water
}

\author{
Khalida M. Omar \\ Hanan H. Ahmed \\ Luma T. Daood \\ Department of Chemistry \\ College of Science \\ Mosul University
}

(Received 8/6/2009 ; Accepted 7/6/2010)

\begin{abstract}
A simple and sensitive procedure for spectrophotometric determination of yttrium (III) in aqueous solution has been developed. The method is based on the reaction of yttrium with pyrocatechol violet at $\mathrm{pH} 7.6$ to form a blue-violet complex which has maximum absorption at $595 \mathrm{~nm}$. Beer's law is obeyed over the concentration range $1-100 \mu \mathrm{g} / 25 \mathrm{ml}$, (i.e., $0.04-4.0 \mathrm{ppm}$ ) of yttrium with a molar absorptivity of $8.365 \times 10^{3} 1 . \mathrm{mol}^{-1} . \mathrm{cm}^{-1}$. The accuracy (relative error) is $(+0.33--0.31 \%)$ and relative standard deviation is better than $\pm 1.63 \%$. The method has been successfully applied to the determination of yttrium in river and sea water .

\section{القدير الليفي لليتربوم بلستخدلم الكلثف بِليروكانيكل البفسبي}

\section{الملغص}

يتضمن البمث ظويرطريقةطفية بسيطة ومسلسة لقدير اليتريوم في المحل _ول الم ائي ـ ـتّ ضمن الطريقة مفاعلة اليتريوه مع الكلثف بايروكاتيكول البفسجي عند الدالة الحلمضية 7.6 لتكوين معقد بف سبجي

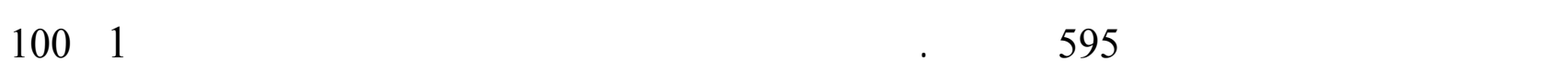

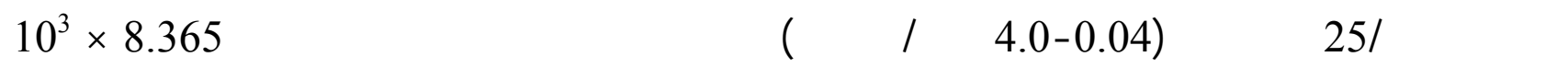

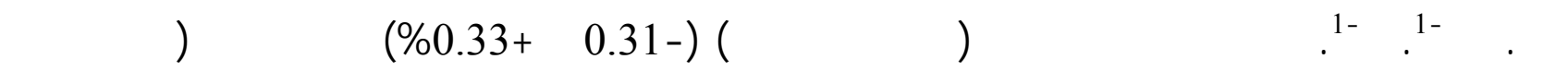

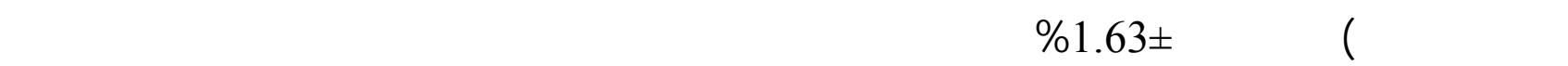
وماء البحر.
\end{abstract}

